トピックス

\title{
ラジカルSAM酵素における反応中間体捕捉と 反応機構解析
}

堀谷正樹 佐賀大学農学部生命機能科学科

\section{1. ラジカル SAM 酵素スーパーファミリー}

ラジカル SAM（S-アデノシルメチオニン）酵素スー パーファミリーはヒトを含む高等生物からバクテリア まで全生物が保有していることが知られており，現在 ではその数が 113,000 種を超える自然界最大の酵素 スーパーファミリーである. すべてのラジカル SAM 酵素は活性中心に特異な $[4 \mathrm{Fe}-4 \mathrm{~S}]$ クラスターを持ち, 3つの鉄イオンは-CX3CX2C-モチーフで保存されてい るシステイン残基と結合しているが，残りのひとつの 鉄イオンは酵素と共有結合をしておらず，“空の”結 合サイトを持っている. Hoffman らは電子・核二重共 鳴（ENDOR）法を用いてラジカル SAM 酵素スーパー

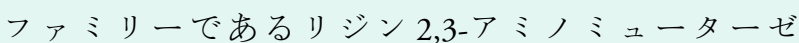
（LAM）とピルビン酸ギ酸リアーゼ活性化酵素（PFLAE）を調べ，それらの反応休止状態で SAM のメチオ ニン部分と特異な鉄イオンがキレート結合を持ってい ることを報告した (図 1 左上) ${ }^{1}$. 現在いくつかのラ ジカル SAM 酵素に拈いて SAM 結合型の結晶構造が 報告されており，X-線結晶構造解析からもこのキレー ト構造が追認されている2).

\section{5'-デオキシアデノシルラジカル}

ラジカル SAM 酵素の酵素反応では，反応第一段階 として還元型 $[4 \mathrm{Fe}-4 \mathrm{~S}]^{+}$クラスターから 1 電子が SAM に受け渡され，SAM の S-C 5' 結合の還元的開裂により 5'-デオキシアデノシル（5'-dAdo•） ラジカルとメチオ ニンが生じると考えられている（図１上），反応第二 段階ではすべてのラジカル SAM 酵素がこのラジカル を利用して様々な基質から水素原子の引き抜きを行 い，基質ラジカルと5'-デオキシアデノシンが生じる. その後，産出した基質ラジカルはそれぞれの酵素に依 存した多種多様な酵素反応に利用される。このように 「単一種のラジカル中間体」を利用して多様な酵素反 応を触媒する点は非常にユニークである。また SAM には3つの S-C 結合が存在するが，ラジカル SAM 酵
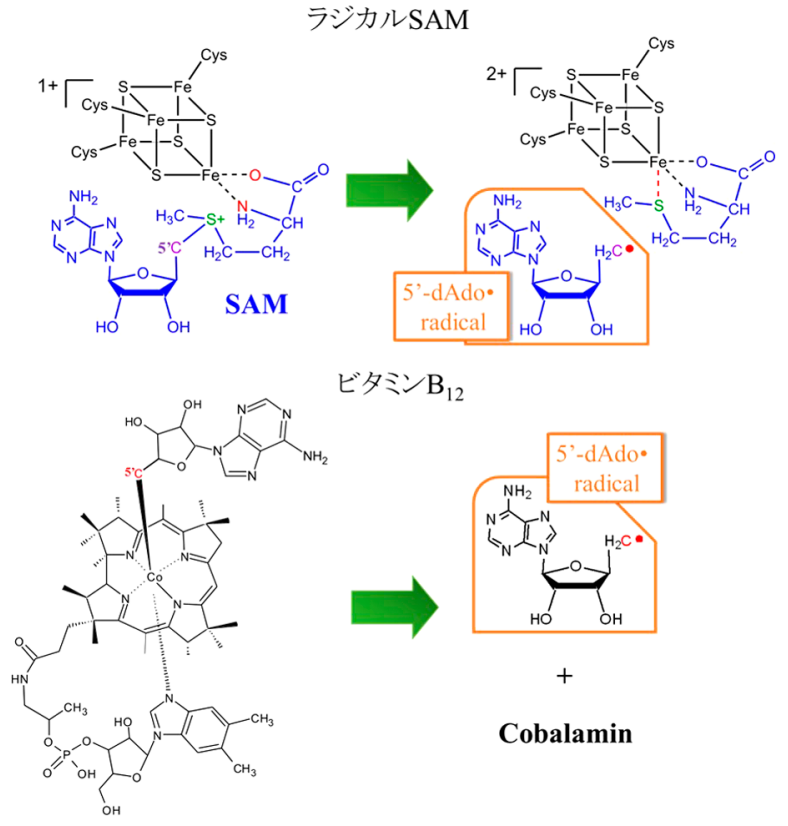

ビタミン $\mathrm{B}_{12}$

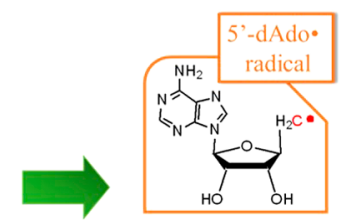

Cobalamin

図 1

ラジカル SAM 酵素とビタミン B12 補酵素における 5'-dAdo・ラジ カル中間体の産出.

素によるSAM の開裂反応はS-C5'結合でしか起こら ない。一体どのようにして酵素が SAM の S-C5'結合 を選択的に認識・開裂しているのか，そのメカニズム は現在のところ不明である.

一方，動物にしか存在しておらず，その数も 12 種 類しかないビタミン $\mathrm{B}_{12}$ 補酵素は活性中心にアデノシ ルコバラミンを持つ(図 1下)。ビタミン $\mathrm{B}_{12}$ の酵素 反応では Co-C5' 結合の開裂により生じる $5^{\prime}$-dAdo・ラ ジカルを利用して，基質より水素原子引き抜き反応を 行 ${ }^{3)}$. ラジカル SAM 酵素とビタミン $\mathrm{B}_{12}$ 補酵素では 同じラジカル中間体を利用することで酵素反応を行っ ているが，双方ともにこのラジカル中間体が直接観 測・捕捉された例はない.

Trapping of the Reaction Intermediates and Analysis of Enzymatic Catalytic Reaction on Radical SAM Enzymes Masaki HORITANI

Department of Applied Biochemistry and Food Science, Faculty of Agriculture, Saga University 


\section{3.|ピルビン酸ギ酸リアーゼの酵素反応中間体の 捕捉・同定}

PFL-AE は比較的研究が進んだラジカル SAM 酵素の ひとつである ${ }^{2)}$ 。この酵素は 5'-dAdo・ラジカルにより 別の酵素であるピルビン酸ギ酸リアーゼ（PFL）の 734 番目グリシンから水素原子を引き抜くことでPFLを活 性化（グリシルラジカル化）する反応を触媒している. この反応系に扣いて，短寿命反応中間体を捕捉するた めに，高速混合凍結法（RFQ）を用いた。 まず PFL-AE の還元型を作成するのに嫌気下での光還元法を用い た.この手法のメリットは光照射を止めると同時に還 元が止まることである。つまり，還元型 PFL-AEが一 度 SAMへ電子を渡し，5'-dAdo・ラジカルを生じさせる と, 酸化型 $[4 \mathrm{Fe}-4 \mathrm{~S}]^{2+}$ クラスターになり, 再度光照射 しない限り再還元されない。このようにしてシングル ターンオーバーの酵素反応条件を達成した. 光還元し たPFL-AE 溶液に対し 1 当量のPFL と 10 当量のSAM 混合溶液を RFQ ミキサー中で混合し，あらかじめ液 体窒素で冷やした高速回転中の銅製ローラーに噴霧す ることで反応を止めた（図 2). この際，流速やミキ サーとローラー間の距離を変えることで反応開始から の経過時間を任意に変えた中間体捕捉が出来る. PFL$\mathrm{AE}$ と PFL/SAM 溶液を混合し， $25 \mathrm{~ms} \sim 1 \mathrm{~s}$ の時間帯で 反応を止め電子スピン共鳴（EPR）装置による観測を 行ったところ，新規の EPR 信号が $12 \mathrm{~K}$ で観測（ $\Omega$ 中 間体と名付ける) された（図 2 黄色吹き出し) ${ }^{4}$. この $\Omega$ 中間体の信号強度は $500 \mathrm{~ms}$ で最大になり，その後 減少していく． $500 \mathrm{~ms}$ で反応をクエンチした $\Omega$ 中間 体について，温度アニーリング法により，試料の温度 を $220 \mathrm{~K}$ まて段階的に上げ，反応をゆっくり進めると $\Omega$ 中間体の信号強度の減少とともに生成物であるグリ シルラジカルの生成が確認された。 これは $\Omega$ 中間体

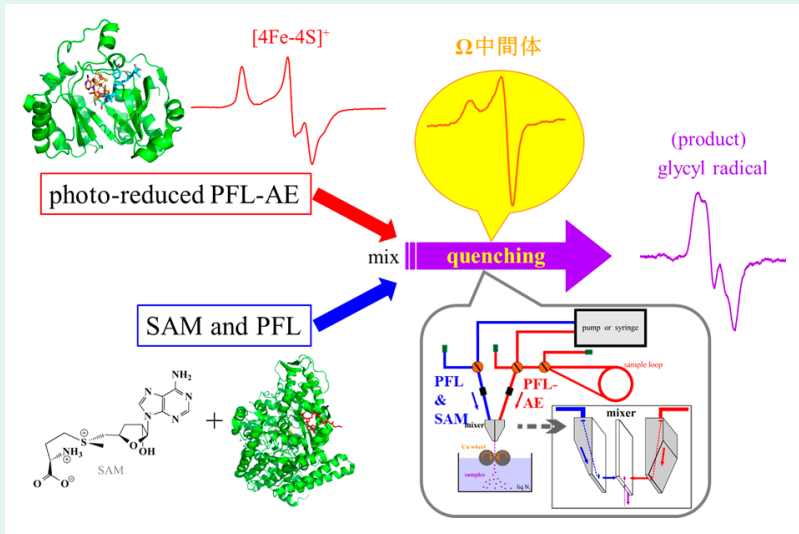

図 2

還元型 PFL-AE と SAM・PFL 混合溶液による高速混合凍結法による 実験模式図と反応開始前, 中間体, 生成物の EPR 信号.
が PFL-AE 反応における酵素反応中間体であることを 示している.さらに， $\Omega$ 中間体の構造解析を行らた め, 部位特異的同位体ラベル $\left({ }^{13} \mathrm{C}\right)$ した SAM や PFL 変異体 $(\mathrm{G} 734 \mathrm{~A}),{ }^{57} \mathrm{Fe}$ 置換 PFL-AE について $\Omega$ 中間体 を捕捉し，ENDOR測定を行った．ENDOR法は電子 スピン周辺の核スピンに関する情報を与えてくれる （NMR on EPR と呼ばれることもあり，超高感度 NMR である)。そのため, ENDOR 信号のスペクトル解析よ り電子スピンと核スピン間の相互作用（結合状態や距 離）に関する情報が得られるため，金属タンパク質研 究における活性中心周辺の溶液 / 結晶構造解析に威力 を発揮する手法である。 ${ }^{13} \mathrm{C}$ および ${ }^{57} \mathrm{FeENDOR}$ 信号を 解析した結果， $\Omega$ 中間体の電子スピンは $[4 \mathrm{Fe}-4 \mathrm{~S}]$ クラ スターに分布しており，5'-dAdoのC5'と直接共有結合 $\left({ }^{13} \mathrm{C}\right.$ 結合定数: $A$ (isotropic) $=9.4 \mathrm{MHz}, 2 T$ (dipole) $\sim 5.3$ $\mathrm{MHz})$ していることが明らかになった。 また $\Omega$ 中間 体の特異な EPR 信号 $(g$ (average $\left.)>g_{\mathrm{e}}=2.003\right) よ り, \Omega$ 中間体は高酸化状態 $[4 \mathrm{Fe}-4 \mathrm{~S}]^{3+}$ クラスターに 5'-dAdo が 共有結合した有機金属中間体であると考えられる (図 3).

\section{4. ラジカル SAM 酵素におけるラジカル反応機構}

$\Omega$ 中間体はこれまで予想されていた反応経路にはな い反応中間体であった。それではどのようにして $\Omega$ 中間体が形成され，酵素反応に利用されているのだろ らか. これまで筆者らが行ってきた研究から考え得る 反応機構を図 3 に示す。従来 SAM の開裂は 1 電子が 鉄硫黄クラスターより SAM に受け渡されることで起 こる（図３上経路）と考えられて扣り，この電子伝 達経路は $\mathrm{Fe} \rightarrow \mathrm{S}$ (SAM) であると予測されていた ${ }^{5)}$. これが正しいとすると，電子伝達後 S-C5' 結合の開裂 が起こり 5'-dAdo・ラジカルが生じる。 ところが5'dAdo・ラジカルは高反応性であるため, すぐに鉄硫黄 クラスターの鉄イオンと共有結合を作る（ $\Omega$ 中間体） ことで安定化しているのではないかと予想される。一 方で SAM の電子伝達反応なしで $\Omega$ 中間体が形成さ

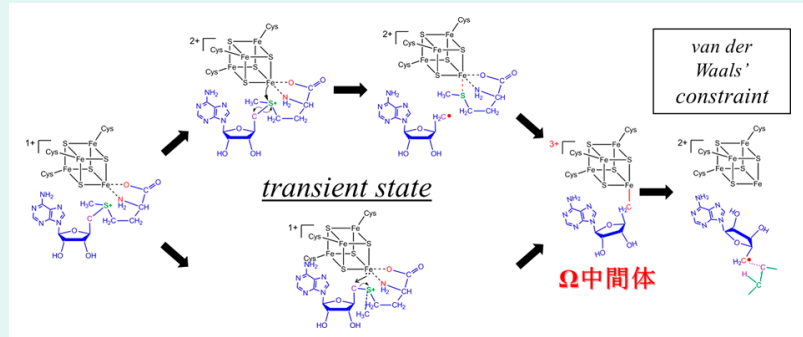

図 3

PFL-AE におけるラジカル反応機構. 
れる可能性もある(図 3 下経路)。こちらの経路では まずSAM のアデノシンとメチル基の入れ替えが起こ り，C5'が鉄硫黄クラスターに近接する．その後，鉄 イオンの非共有電子対が求核反応的にデオキシアデ, シンと結合を作る．両経路での重要な違いは $\Omega$ 中間 体形成に高反応性ラジカルの産出が必要であるかとい らことである.この問題にはより速い時間での中間体 捕捉が必要か子知れない， $\Omega$ 中間体はまさしくビタミ ン $\mathrm{B}_{12}$ 補酵素にみられるアデノシルコバラミン様化合 物であり, $\Omega$ 中間体形成後は Fe-C5 ${ }^{\prime}$ 結合の開裂によ り 5'-dAdo・ラジカルが産出し, 基質より水素原子引き 抜き反応が起こると考えられる。

PFL-AE の結晶構造に $\Omega$ 中間体構造をモデル化する と, $\mathrm{Fe}-\mathrm{C} 55^{\prime}$ 結合開裂後アデニンとリボース環の C-N 結合がッイストするだけで基質の水素原子引き抜き反 応が起こり得ることが分かってきた。つまり，ラジカ ル産出後は非常に制限された動きで酵素反応が達成で きる構造基盤を PFL-AE は持っていることを示唆して いる．さらに以前筆者らはSAM アナログを合成する ことで5'-dAdo・ラジカルアナログ中間体の捕捉に成功 している. この詳細な解析では 5'-dAdo・ラジカルが基 質より水素原子を引き抜く際，引き抜きターゲットで はなく，近接した基質炭素原子とファンデルワールス 結合していることが明らかになった ${ }^{6}$ ，この弱い結合 力もまた高反応性ラジカルの自由度を制限していると 考光られる (図3右)。つまり PFL-AEでは，高反応 性 5'-dAdo・フリーラジカルは $(1) \Omega$ 中間を形成するこ と, (2)ラジカルの動きを制限していること, (3)基質と のファンデルワールスカにより捕捉されていること, を利用して副反応を起こさないようにラジカルを上手 く使う仕組みを持っていると言える.

PFL-AE の酵素反応では有機金属化合物である $\Omega$ 中 間体を経て酵素反応を触媒していることが明らかに なった，有機金属錯体（金属イオンと炭素間に結合， 但し一酸化炭素やシアンイオンは除く）は一般的に水 溶液中では不安定であるため, 自然界には存在しない と考觉られていた。 ところが，ビタミン $\mathrm{B}_{12}$ 補酵素が 有機金属錯体であるコバラミンを活性中心に持つこと が明らかになり7)，さらに窒素還元醰素の変異体にお ける酵素反応でも活性中心の $\mathrm{FeMo}$ コファクターの鉄 イオンと基質（アルコール）とで有機金属化合物の形 成が観測され ${ }^{8)}$ ，また水素還元酵素などでも有機金属 化合物が利用されている。るし $\Omega$ 中間体がすべての ラジカル SAM 酵素に共通の中間体であれば，自然界 は積極的に有機金属化合物を利用していると言えるだ ろう。ささらなる実験・検証が必要である。

\section{5. おわりに}

世界的にみても現在多種のラジカル SAM 酵素の機 能解析が進められており，新規のラジカル SAM 酵素 / 鉄硫黄クラスタ一の反応性・機能性が続々と報告さ れている、筆者らも特異なラジカル SAM 酵素である ジフタミド生合成酵素において， $\Omega$ 中間とは別種の有 機金属中間体を報告した ${ }^{9)}$ 。をた最近，ラジカルが鉄 硫黄クラスターの硫黄原子と結合する可能性や，酵素 によるSAM 開裂選択機構についても報告した ${ }^{10)}$ 。最 近の鉄硫黄クラスタ一酵素における潮流を眺めるとま だまだ未知の機能があるに違いない。

謝 辞

本稿における実験は Northwestern Univ の Brian M. Hoffman 教授のもとで行った研究であり，試料の提供 は Montana State Univ の Joan B. Broderick 教授によるも のである.ここに謝意を表します。

文 献

1) Walsby, C. J. et al. (2002) J. Am. Chem. Soc. 124, 11270-11271. DOI: $10.1021 / \mathrm{ja} 027078 \mathrm{v}$.

2) Broderick, J. B. et al. (2014) Chem. Rev. 114, 4229-4317. DOI: $10.1021 /$ cr4004709.

3) Warnke, K., Utada, A. S. (2001) J. Am. Chem. Soc. 123, 85648572. DOI: $10.1021 /$ ja 0036581 .

4) Horitani, M. et al. (2016) Science 352, 822-825. DOI: $10.1126 /$ science.aaf5327.

5) Kampmeier, J. A. (2010) Biochemistry 49, 10770-10772. DOI: 10.1021/bi101509u.

6) Horitani, M. et al. (2015) J. Am. Chem. Soc. 137, 7111-7121. DOI: $10.1021 /$ jacs.5b00498.

7) Banerjee, R., ed. (1999) Chemistry and Biochemistry of B12, John Wiley \& Sons, New York.

8) Lee, H. -I. et al. (2004) J. Am. Chem. Soc. 126, 9563-9569. DOI: $10.1021 / \mathrm{ja} 048714 \mathrm{n}$.

9) Dong, M. et al. (2016) J. Am. Chem. Soc. 138, 9755-9758. DOI: 10.1021/jacs.6b04155.

10) Dong, M. et al. (2017) J. Am. Chem. Soc. 139, 5680-5683. DOI: 10.1021/jacs.7b01712.

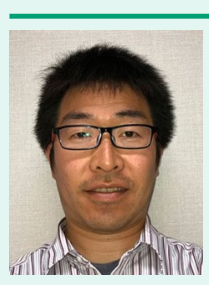

堀谷正樹
堀谷正樹（ほりたに まさき） 佐賀大学農学部生命機能科学科助教 2008 年大阪大学大学院基礎工学研究科博士後期 課程修了, 博士 (理学), 理化学研究所特別研究 員, Northwestern Univ., ポスドクを経て 16 年よ り現職.

研究内容:先端磁気共鳴法による生物無機化学研究 連絡先: 于 840-8502 佐賀市本庄町 1

E-mail: horitani@cc.saga-u.ac.jp URL: http://www.ag.saga-u.ac.jp/japanese/mollifesci/ mollifesci.html 